\title{
In liquid medium colchicine treatment induces non chimerical doubled-diploids in a wide range of mono- and interspecific diploid banana clones
}

Frédéric BAKRY ${ }^{a *}$, Nilda PAUlo de LA Reberdiere ${ }^{b}$, Sylvain PICHOT $^{c}$, Christophe JeNNY

\begin{abstract}
a Cirad, UPR Multiplication végétative, TA50 / PS4, Boulevard de la Lironde, 34398 Montpellier, Cedex 5, France

bakry@cirad.fr

${ }^{\mathrm{b}}$ Cirad, UPR Multiplication végétative, Station de Neufchâteau, Sainte-Marie, 97130 Capesterre Belle Eau, Guadeloupe, France
\end{abstract}

${ }^{\mathrm{c}}$ Rue du Saulcy-Pitou, 54110 Dombasle, Meurthe, France

${ }^{*}$ Correspondence and reprints

Received 13 July 2006 Accepted 25 September 2006

Fruits, 2007, vol. 62, p. 3-12 (C) 2007 Cirad/EDP Sciences All rights reserved DOI: $10.1051 /$ fruits:2006043 www.edpsciences.org/fruits

RESUMEN ESPAÑOL, p. 12
In liquid medium colchicine treatment induces non chimerical doubleddiploids in a wide range of mono- and interspecific diploid banana clones.

Abstract - Introduction. The worldwide production of banana and plantain, which is estimated to $106 \mathrm{Mt} \cdot \mathrm{year}^{-1}$, relies on a narrow genetic basis. Thus, banana production is fragile regarding emergent diseases, and creation of new varieties of banana stands out as a real necessity for its sustainability. In banana, various improvement strategies aim to create triploid hybrids. The objective of this report is to present a simple in vitro methodology to induce stable tetraploid plants by colchicine treatment, usable as parent for obtaining triploid varieties. Materials and methods. Twenty-one diploid M. acuminata clones and three interspecific M. acuminata / M. balbisiana diploid clones were treated as proliferating culture in liquid medium with $1.25 \mathrm{mM}$ of colchicine for $48 \mathrm{~h}$. Plant screening has been performed by morphological identification in greenhouse, chromosome counts on root tips and flow cytometry on leave blades on vitroplants using propidium iodide staining. Results. Chromosome counts led to distinguish diploid and tetraploid plants but did not afford to detect chimeras. Flow cytometry allowed an early screening of a larger number of plants leading to detect rapidly chimerical plants. It was observed that some stable $2 \mathrm{x} / 4 \mathrm{x}$ cytochimeras are periclinal. Tetraploid clones were obtained with all diploid genotypes. General behaviour of tetraploids in the field was globally weaker than the corresponding diploids. Nevertheless, all the doubled-diploids flowered and crossed with diploid plants to obtain triploid progenies. Conclusion. This study has clearly shown that induction of stable doubled-diploid plants can be obtained from a wide range of genetically different bananas. These results open the way to the systematic use of doubled-diploids by banana breeding programs for the release of enhanced triploid varieties.

Guadeloupe / Musa / tissue culture / colchicine / chromosome number / tetraploidy / chimeras

La colchicine appliquée en milieu liquide induit des diploïdes doublés non chimériques dans une large gamme de clones de bananiers diploïdes mono ou interspécifiques.

Résumé - Introduction. La production mondiale de bananes et plantains, qui est estimée à $106 \mathrm{Mt} \cdot \mathrm{an}^{-1}$, s'appuie sur une base génétique étroite. La production de bananes est donc fragile quant à la menace des maladies émergentes et la création de nouvelles variétés apparaît comme une réelle nécessité pour sa pérennité. Les diverses stratégies d'amélioration du bananier visent à créer des hybrides triploïdes. L'objectif de cet article est de présenter une méthode aisée de production de plantes tétraploïdes stables par traitement de colchicine appliqué in vitro, utilisables comme parents pour obtenir de nouvelles variétés hybrides triploïdes. Matériel et méthodes. Vingt-et-un clones diploïdes de $M$. acuminata et trois clones diploïdes interspécifiques $M$. $a c u$ minata / M. balbisiana ont été traités durant la phase de prolifération invitro dans un milieu liquide avec 1,25 mM de colchicine pendant $48 \mathrm{~h}$. Le tri des plants a été effectué par une identification morphologique en serre, le comptage des chromosomes a été fait sur les pointes de racines et la cytométrie de flux sur fragments de feuilles de vitroplants en utilisant l'iodure de propidium comme colorant. Résultats. Le comptage des chromosomes a été efficace pour distinguer les plants diploïdes et tétraploïdes mais il n'a pas pu permettre de détecter les chimères. La cytométrie de flux a permis un criblage précoce d'un plus grand nombre de plants et a conduit à la détection rapide des plants chimériques. Il a été noté que quelques cytochimères $2 \mathrm{x} / 4 \mathrm{x}$ stables étaient périclinales. Des clones tétraploïdes ont été obtenus avec tous les génotypes diploïdes. En général, les tétraploïdes au champ se sont révélés moins vigoureux que les diploïdes correspondants. Néanmoins, tous les diploïdes doublés ont fleuri et ont été croisés avec des plants diploïdes pour obtenir des descendances triploïdes. Conclusion. Notre étude a clairement montré que l'induction de plants stables de diploïdes doublés peut être obtenue à partir d'une large gamme de bananiers génétiquement différents. Ces résultats ouvrent la voie à l'utilisation systématique de diploïdes doublés par les programmes d'amélioration pour l'obtention de variétés triploïdes améliorées de bananiers. Guadeloupe / Musa / culture de tissu / colchicine / nombre chromosomique / tétraploïdie / chimère 


\section{Introduction}

The worldwide production of banana and plantain is estimated to $106 \mathrm{Mt}$ per year ${ }^{1}$, of which $15 \mathrm{Mt}$ are intended for the exportation markets and the remainder in food producing culture or for the supply to the local markets. The banana and plantain productions, which contribute to the basic nutrition closely of $400 \mathrm{M}$ of individuals in the world, are subject to an increasing pressure of the diseases, of which the principal is the Black Leaf Streak Disease [1].

Most of the natural varieties are triploid, seedless and propagated by suckers. They are derived from the sole Musa acuminata species (AAA cv.) or from M. acuminata and $M$. balbisiana intercrosses (AAB cv. and $\mathrm{ABB}$ cv.). Diploid varieties (AA cv. and AB $\mathrm{Cv}$.) are less important [2] and natural tetraploids are very few. The current triploid varieties result from crosses between two diploid varieties in which one parent contributes a diploid gamete [2-4].

More than $45 \%$ of the world production relies on one narrow genetic subgroup, Cavendish, in which natural variability relies only on small mutation processes. Thus, banana production requires phytosanitary protections and is fragile regarding emergent diseases. Therefore, the creation of new varieties of banana stands out as a real necessity for production sustainability.

In banana, various improvement strategies aim to create triploid hybrids [5]. In diploids, Dodds and Simmonds [6] described how abnormal meiosis occurs in banana and induces diploid spores. Nevertheless, gamete restitution is fairly rare [7]. Thus, chromosome doubling applied to diploid clones is shown as an alternative pathway to systematize the obtention of triploids from crosses between diploids and doubled diploids.

Polyploidisation in banana was first induced by Vakili [8] by immersion of $M$. balbisiana germinating seeds in a colchicine solution. The recovered plantlets showed to be tetraploid and octoploid, some tetraploids reverting to diploid level. These first

${ }^{1}$ http://faostat.fao.org/ results on seeds were later confirmed by Dessauw [9] and Asif [10] on M. balbisiana and various $M$. acuminata subspecies and by Tesfaye [11] in the species Ensete ventricosum.

In 1992, Hamill et al. [12] reported first the induction of autotetraploid in the SH-3362 diploid edible hybrid. Polyploidisation resulted from the in vitro application of $1.25 \mathrm{mM}$ (e.g., $0.5 \mathrm{w} / \mathrm{v}$ ) colchicine for $2 \mathrm{~h}$ on micropropagated shoot tips in liquid medium. Selection of inducted tetraploids relied on gross morphology and stomatal characters. Stable autotetraploids have been established in the field, but reversions, formation of chimeras and aneuploids were common. Later, Van Duren et al. [13] compared, in similar in vitro conditions, the efficiency of colchicine and oryzalin to induce polyploidisation on the same SH-3362 clone. Most effective in producing non-chimerical tetraploids was $30 \mu \mathrm{M}$ oryzalin for 7 days or $5 \mathrm{mM}$ colchicine for $48 \mathrm{~h}$. More recently, Ganga et al. [14] also reported the efficiency of colchicine in tetraploid induction of four mono- (AA) and interspecific (AB) Indian diploid banana cultivars. Clones were selected based on stomatal densities and chloroplast traits. Nevertheless, no mention was given on the stability of the regenerated tetraploids in the field.

The objective of our report is to present a simple in vitro methodology to induce stable tetraploids in bananas by colchicine treatment in a wide range of natural and synthetic edible diploid bananas. This methodology was used over a period of more than 15 years with a good efficiency. An efficient screening procedure by chromosome counts on root tips and flow cytometry is also presented.

\section{Materials and methods}

\subsection{Plant material}

All the diploid plant material used in our experiment was obtained from the Centre de Cooperation Internationale en Recherche Agronomique pour le Développement (CIRAD), Research Station of Neufchateau 
Table I.

Characterization of 25 diploid Musa clones used to test the efficacy of colchicine treatment in order to induce doubled-diploids.

\begin{tabular}{|c|c|c|c|c|c|c|c|c|}
\hline \multirow{2}{*}{$\begin{array}{l}\text { No. of } \\
\text { the } \\
\text { clone }\end{array}$} & \multirow[t]{2}{*}{ Name of the clone } & \multirow[t]{2}{*}{ No. ITC ${ }^{1}$} & \multirow[t]{2}{*}{ Status } & \multirow[t]{2}{*}{$\begin{array}{c}\text { Genetic } \\
\text { constitution }\end{array}$} & \multicolumn{2}{|c|}{$\begin{array}{c}\text { Cytoplasmic } \\
\text { characterization }^{2}\end{array}$} & \multirow[t]{2}{*}{ Use } & \multirow[t]{2}{*}{ Origine } \\
\hline & & & & & Cp pattern & Mitotype & & \\
\hline 1 & AA cv. Rose & ITC 0712 & Natural & $A A$ & ॥ & $\alpha$ & Dessert type & Indonesia \\
\hline 2 & Colatina Ouro & ITC 0260 & Natural & AA & ॥ & $\alpha$ & Dessert type & Brazil \\
\hline 3 & IDN 077 & ITC 0688 & Natural & AA & II & $\alpha$ & Dessert type & Indonesia \\
\hline 4 & Gu Nin Chiao & ITC 0442 & Natural & AA & ॥ & $\alpha$ & Dessert type & Singapore \\
\hline 5 & Khai Nai On & ITC 0663 & Natural & $A A$ & ॥ & $\alpha$ & Dessert type & Thailand \\
\hline 6 & Kirun (=Sucrier) & - & Natural & AA & ॥ & $\alpha$ & Dessert type & Guadeloupe \\
\hline 7 & Manang & ITC 0297 & Natural & $A A$ & ॥ & $\alpha$ & Dessert type & Philippines \\
\hline 8 & No. 110 / Tha 052 & - & Natural & AA & ॥ & $\alpha$ & Dessert type & Thailand \\
\hline 9 & Pisang Lilin & ITC 0001 & Natural & $A A$ & ॥ & $\delta$ & Dessert type & Malaysia \\
\hline 10 & Pisang Madu & ITC 0258 & Natural & AA & V & $\alpha$ & Dessert type & Malaysia \\
\hline 11 & Pisang Pipit & ITC 0685 & Natural & AA & ॥ & $\alpha$ & Dessert type & Indonesia \\
\hline 12 & Pisang Trimulin & ITC 0699 & Natural & AA & III & $\alpha$ & Dessert type & Indonesia \\
\hline 13 & $\mathrm{Sa}$ & ITC 0673 & Natural & AA & ॥ & $\alpha$ & Dessert type & Thailand \\
\hline 14 & Tjau Lagada & ITC 0090 & Natural & $A A$ & III & $\alpha$ & Dessert type & Indonesia \\
\hline 15 & Bebeck & ITC 0471 & Natural & AA & V & $\alpha$ & Cooking type & Irian Jaya \\
\hline 16 & Bie Yeng & ITC 0279 & Natural & AA & V & $\alpha$ & Cooking type & Papua New Guinea \\
\hline 17 & Galéo & ITC 0259 & Natural & AA & V & $\alpha$ & Cooking type & Papua New Guinea \\
\hline 18 & Guyod & ITC 0299 & Natural & $A A$ & ॥ & $\alpha$ & Cooking type & Philippines \\
\hline 19 & Gwanhour & ITC 0256 & Natural & AA & V & $\varphi$ & Cooking type & Papua New Guinea \\
\hline 20 & Heva & ITC 0257 & Natural & AA & V & $\alpha$ & Cooking type & Papua New Guinea \\
\hline 21 & NBB11 / SF265 & ITC 0270 & Natural & AA & V & $\alpha$ & Cooking type & Papua New Guinea \\
\hline 22 & Tomolo & ITC 1187 & Natural & AA & V & $\alpha$ & Cooking type & Papua New Guinea \\
\hline 23 & Col 49 - Guyod × Galéo & - & CIRAD hybrid & $A A$ & V & $\alpha$ & Cooking type & Guadeloupe \\
\hline 24 & Kunnan & ITC 1034 & Natural & $A B$ & ॥ & $\delta$ & Dessert type & India \\
\hline 25 & Gu 56 - BB × Galéo & - & CIRAD hybrid & BA & VIII & $\alpha$ & Cooking type & Guadeloupe \\
\hline
\end{tabular}

in Guadeloupe (F.W.I.). These diploid clones were classified according to Carreel et al. [3]: twenty-one diploids are natural dessert or cooking M. acuminata clones. One natural interspecific AB clone (cv. Kunnan), one experimental interspecific BA cooking type hybrid and one experimental AA cooking type hybrid were also experimented (table I). These clones are representative of the wide genotypic and phenotypic diversity of the edible diploid bananas around the world [2].

\subsection{Methods}

\subsubsection{Establishment of the proliferating culture}

Tissue cultures were initiated from shoot tips taken from banana suckers. For sterilisation, banana suckers were reduced to explants of $2-3 \mathrm{~cm}$ in length and $2 \mathrm{~cm}$ in diameter; they were then immersed in $95 \%$ (v/v) ethanol, followed by flaming. Flaming was repeated two times. Burned tissues 
were then discarded, in sterile conditions, up to innermost intact tissues. Shoot apices were placed onto $100 \mathrm{~mL}$ of a solid proliferating medium containing MS macro- and microelements [15], vitamins from Morel [16], $88 \mathrm{mM}$ sucrose, $22.2 \mu \mathrm{M}$ 6-benzylaminopurine (BAP), $651.5 \mu \mathrm{M}$ adenine sulphate and $7 \mathrm{~g} \cdot \mathrm{L}^{-1}$ agar. The $\mathrm{pH}$ of the medium was adjusted to 5.8 before autoclaving. Cultures were kept at $27{ }^{\circ} \mathrm{C}$ in darkness for 45 days. Active multiplication occurred following subdivision of bud clusters and subculture of individual pieces on proliferating medium in the same conditions for more than 45 days. At this stage, the explants were divided to sub-explants of 2-cm diameter and individually transferred, for 10 days, to Erlenmeyer flasks containing $125 \mathrm{~mL}$ of proliferating liquid medium of same composition but complemented with 3mM 2-[N-morpholino] ethanesulfonic acid (MES) and without agar. All the cultures in liquid medium were performed on a gyratory shaker $(120 \mathrm{rpm})$ in a growth chamber at $27^{\circ} \mathrm{C}$ and $16 / 8 \mathrm{~h}$ (day / night) photoperiod (Mazda "daylight" fluorescent tubes, $\left.100 \mu \mathrm{mol} \cdot \mathrm{m}^{-2} \mathrm{~s}^{-1}\right)$.

\subsubsection{Colchicine treatment and plant recovery}

The proliferating clusters were subdivided again and individually subcultured in $125 \mathrm{~mL}$ of the proliferating liquid medium supplemented with $1.25 \mathrm{mM}$ colchicine (dissolved in 90\% ethanol) for $48 \mathrm{~h}$. Explants were then taken out of the flasks, placed in $125 \mathrm{~mL}$ of sterile distilled water for 2 days and transferred in the proliferating liquid medium for 15 days. The clusters were then replaced on the proliferating solid medium until bud proliferation. Buds were isolated from the cultures and subcultured onto the hormone-free solid medium (without BAP and adenine sulfate) to allow growth of the shoots.

Grown microshoots were isolated from the clusters and then placed individually in tubes on the hormone-free solid medium to induce formation of elongated shoots and roots. The plantlets were transferred 30 to 40 days later to nursery on an artificial substrate (Giffy-7, Giffy Products Ltd., Norway), at a temperature of $25-26{ }^{\circ} \mathrm{C}$ at night and $30-35^{\circ} \mathrm{C}$ during the day, under natural light of $40-150 \mu \mathrm{mol} \cdot \mathrm{m}^{-2} \cdot \mathrm{s}^{-1}$ and $75-100 \%$ relative humidity. Thirty days later, plants were finally transferred to 3-L pots with a mixture of river sand and peat, enriched with $10 \mathrm{~g}$ per plant of complete fertilizer (N-P-K and microelements), and put in greenhouse.

\subsubsection{Plant characterization}

\subsubsection{Morphological identification}

In greenhouse, 45-days-old tetraploid plants were usually more robust stocky and had thicker leave blades than diploids. Tetraploids also showed a higher resistance to rolling up of leave blades between fingers than diploids. All these indications were used to early identification, in greenhouse, of putative tetraploids pre-selected for more accurate characterization.

\subsubsection{Chromosome counts}

Chromosome counts were carried out according to Bakry and Horry [17]. The root tips were taken from the plants in the greenhouse between 6:30 A.M. and 8:00 A.M. and placed in $0.03 \%(\mathrm{w} / \mathrm{v})$ hydroxyquinoline solution, open to the air at $20-25^{\circ} \mathrm{C}$ for $6-$ $8 \mathrm{~h}$. The tips were then immersed for at least $3 \mathrm{~h}$ into a macerating/fixing mixture (acetic acid:ethanol:water, 4:1:5). Finally, the root tips were crushed between the microscope slide and cover-slip in a drop of stain [orcein $2 \%(\mathrm{w} / \mathrm{v})$ in a solution of lactic acid:phenol:glycerol:water, 1:1:1:1]. Counting was carried out at $1000(10 \times 100)$ magnification. For each plant, chromosome counts were performed on five to six independent cells from one or two root tips.

\subsubsection{Flow cytometry}

For the flow cytometry studies, samples of $1 \mathrm{~cm}^{2}$ of young plant leaves taken off in the greenhouse were chopped with a razor blade in 55-mm-diameter Petri dishes, containing $0.5 \mathrm{~mL}$ of Phosphate Buffered Saline (PBS) solution as extraction buffer, completed with Triton X-100 (0.25\%) and sodium meta-bisulfite (1\%). The suspension of released nuclei was passed through a $15-\mu \mathrm{m}$ Nylon filter and mixed with $0.2 \mathrm{~mL}$ of extraction buffer supplemented with propidium iodide $(200 \mu \mathrm{g} \cdot \mathrm{mL})$, which is a DNA 
intercalating dye [18]. Before analysis, preparations were maintained for $5 \mathrm{~min}$ in the dark and on ice. Four samples were prepared for each of the clones. Measurements were performed on a FACScalibur Laser flow cytometer (Beckton Dickinson, USA). Histograms of FL2 fluorescence intensity were registered over 1024 channels and studied using WinMDI ${ }^{\circledR}$ software Ver. 2.8.

Measurement of the size of the banana genome was performed with the internal control Citrus limon 'Lisbon', whose absolute genome size had been previously measured at $0.786 \mathrm{pg} /$ 2C [19, 20]. Nuclear 2C DNA content was estimated for each diploid clone with the formula [(average channel number of banana nuclear peak / average channel number of Citrus limon cv. Lisbon peak) $\times 0.786 \mathrm{pg}$.

\subsubsection{Histology}

Histological studies were performed on in vitro banana shoot apex of Americani cv. (Cavendish, AAA) for comparison. Slides were prepared according to Bakry and Rossignol [21].

\section{Results and discussion}

\subsection{Chromosome counts}

For chromosome counts, chromosome should be well separated showing few overlappings so that chromosomes can be unequivocally defined and counted (figure 1).

Chromosome counts were performed in 88 different cells. Root tips taken from the same treated derived plantlets always showed the same chromosome number, either 22 chromosomes in the untreated donor plant, or 44 chromosomes in the colchicine treated ones. No diploid/tetraploid chimera was identified within the same root tip and no plant with higher chromosome content was observed.

\subsection{Flow cytometry}

Flow cytometry used for early ploidy screening led to quantify the DNA content of the

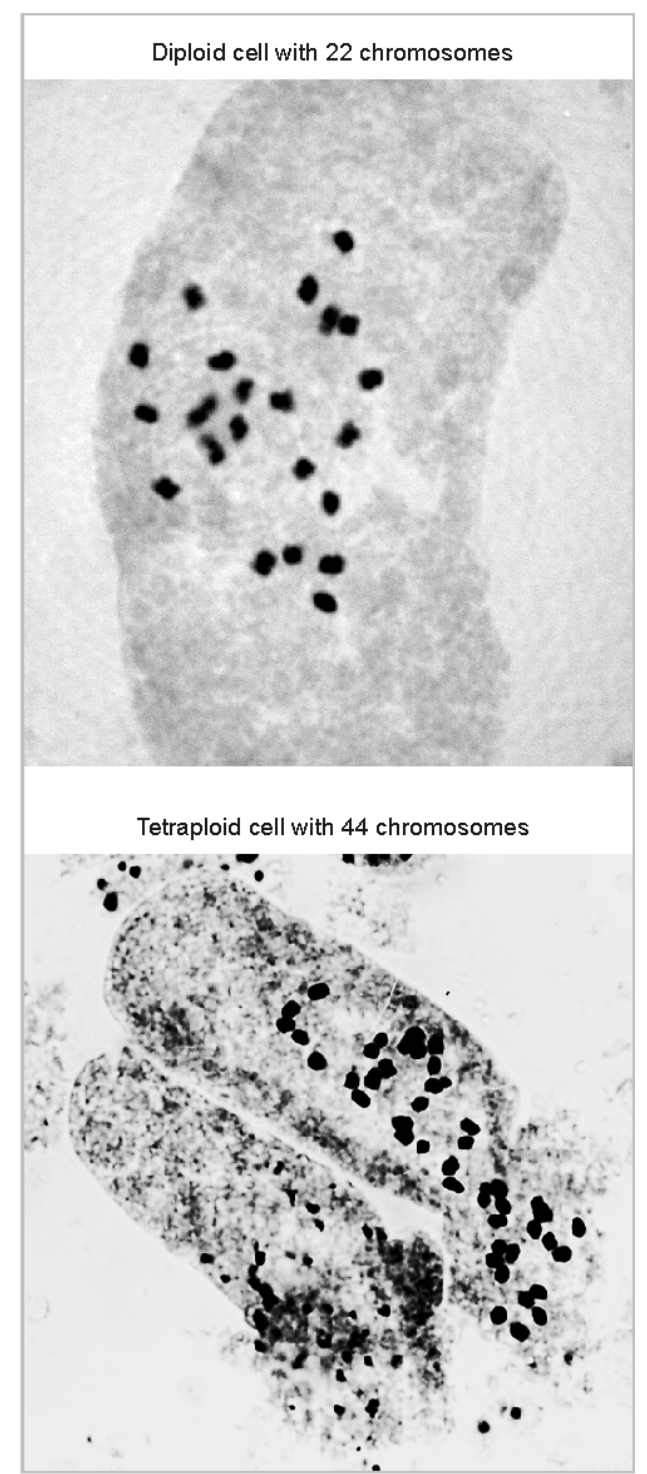

Figure 1.

Chromosome counts: plates showing a diploid cell containing 22 well-separated chromosomes and a tetraploid cell containing

44 chromosomes with some superpositions.
25 diploid varieties submitted to colchicine treatment. Average DNA content of the AA clones was $1.13 \mathrm{pg}$ per nucleus, ranging from $1.07 \mathrm{pg}$ per nucleus for Pisang Lilin to $1.17 \mathrm{pg}$ per nucleus for Bebeck (table II). Kunnan (AB) showed a low DNA content, which is consistent with its interspecific genomic composition, $M$. balbisiana owning one of the smallest DNA content in the Eumusa section (unpublished results). These results are consistent with those of previous reports on Musa [22]. 
Table II.

Ploidy status of 25 Musa clones after in liquid medium colchicine treatments, determined by the use of chromosome counts and flow cytometry.

\begin{tabular}{|c|c|c|c|c|c|c|c|c|c|c|}
\hline \multirow{3}{*}{$\begin{array}{l}\text { No. of the } \\
\text { clone }\end{array}$} & \multirow[t]{3}{*}{ Name of the clone } & \multirow{2}{*}{\multicolumn{2}{|c|}{ Year of analysis }} & \multicolumn{6}{|c|}{ Number of plants analysed by: } & \multirow{3}{*}{$\begin{array}{c}\text { DNA } \\
\text { content } \\
\text { pg/2C }\end{array}$} \\
\hline & & & & \multicolumn{2}{|c|}{$\begin{array}{l}\text { Chromosome } \\
\text { counts }^{1}\end{array}$} & \multicolumn{4}{|c|}{ Flow cytometry ${ }^{2}$} & \\
\hline & & $\begin{array}{c}\text { Chromosome } \\
\text { counts }\end{array}$ & $\begin{array}{l}\text { Flow } \\
\text { cytometry }\end{array}$ & $2 \mathrm{~N}=22$ & $2 \mathrm{~N}=44$ & $2 \mathrm{~N}=22$ & $2 \mathrm{~N}=44$ & $\begin{array}{c}\text { Chimeras } \\
2 N=22 / 44\end{array}$ & $\begin{array}{c}\text { Other } \\
\text { chimeras }\end{array}$ & \\
\hline 1 & AA cv Rose & 1988 & 1993 & 2 & 8 & 0 & 0 & $20^{\star \star}$ & 0 & 1.11 \\
\hline 2 & Colatina Ouro & - & 1995 & - & - & $0^{*}$ & $2^{*}$ & $4^{*}$ & 0 & 1.15 \\
\hline 3 & IDN 077 & - & 2002 & - & - & $3^{\star \star}$ & $6^{\star \star}$ & $8^{\star \star}$ & 0 & 1.10 \\
\hline 4 & Gu Nin Chiao & - & 1995 & - & - & $1^{\star}$ & $2^{\star}$ & $4^{\star}$ & 0 & 1.14 \\
\hline 5 & Khai Nai On & - & 1994 & - & - & $0^{*}$ & $8^{*}$ & $0^{*}$ & 0 & 1.15 \\
\hline 6 & Kirun (=Sucrier) & - & 1998 & - & - & $4^{\star}$ & $18^{\star}$ & $13^{*}$ & 0 & 1.13 \\
\hline 7 & Manang & - & 1995 & - & - & $2^{*}$ & $4^{*}$ & $14^{*}$ & 0 & 1.12 \\
\hline 8 & $N^{\circ} 110 /$ Tha 052 & - & 2004 & - & - & $4^{\star \star}$ & $4^{\star \star}$ & $2^{\star \star}$ & 0 & 1.13 \\
\hline 9 & Pisang Lilin & 1988 & 1993 & 2 & 2 & 0 & $5^{\star \star}$ & 0 & 0 & 1.07 \\
\hline 10 & Pisang Madu & - & 2002 & - & - & $2^{\star \star}$ & $8^{\star \star}$ & $6^{\star \star}$ & 0 & 1.11 \\
\hline 11 & Pisang Pipit & - & 1994 & - & - & 0 & $3^{\star \star}$ & 0 & 0 & 1.15 \\
\hline 12 & Pisang Trimulin & - & 1998 & - & - & $16^{\star}$ & $17^{\star}$ & $33^{*}$ & 0 & 1.15 \\
\hline 13 & $\mathrm{Sa}$ & - & 1994 & - & - & 0 & $11^{\star \star}$ & 0 & 0 & 1.15 \\
\hline 14 & Tjau Lagada & 1988 & 1994 & 2 & 13 & $2^{*}$ & $3^{\star}$ & $4^{\star}$ & 0 & 1.14 \\
\hline 15 & Bebeck & - & 1995 & - & 2 & 0 & $3^{\star \star}$ & $5^{\star \star}$ & 0 & 1.17 \\
\hline 16 & Bie Yeng & 1988 & 1993 & 4 & 3 & 0 & - & $14^{\star \star}$ & 0 & 1.14 \\
\hline 17 & Galéo & 1988 & 1993 & 1 & 3 & 0 & $2^{\star \star}$ & $7^{\star \star}$ & 0 & 1.13 \\
\hline 18 & Guyod & 1988 & 1993 & 6 & 11 & 0 & $9^{\star \star}$ & $1^{\star \star}$ & 0 & 1.16 \\
\hline 19 & Gwanhour & - & 1995 & - & - & $4^{*}$ & $5^{\star}$ & $9^{*}$ & 0 & 1.10 \\
\hline 20 & Heva & - & 1994 & - & - & $2^{*}$ & $12^{*}$ & $1^{*}$ & 0 & 1.14 \\
\hline 21 & NBB11 / SF265 & 1988 & 1993 & 2 & 5 & 0 & $3^{\star \star}$ & 0 & 0 & 1.14 \\
\hline 22 & Tomolo & - & 1995 & - & - & $6^{*}$ & $7^{\star}$ & $2^{*}$ & $1: 4 x / 8 x^{*}$ & 1.11 \\
\hline 23 & Col 49 - Guyod × Galéo & - & 1998 & - & - & $2^{*}$ & $21^{*}$ & $19^{*}$ & $6: 4 x / 8 x$ & - \\
\hline 24 & Kunnan & - & 2004 & - & - & $0^{\star \star}$ & $23^{\star \star}$ & $6^{\star \star}$ & 0 & 1.07 \\
\hline 25 & Gu 56 - BB × Galéo & - & 1995 & - & - & 0 & $4^{\star \star}$ & $1^{\star \star}$ & 0 & - \\
\hline
\end{tabular}

${ }^{1}$ Chromosome counting on roots tips on plantlets in the greenhouse.

${ }^{2}$ Flow cytometry measurements on in vitro plantlets $\left({ }^{*}\right)$ or on plantlets in the greenhouse and/or on plants in the field $\left({ }^{* *}\right)$.

Three different situations were observed for ploidy screening (figure 2):

- histograms with two close peaks, the citrus control on the left and the diploid Musa peak on the right;

- histograms with two distant peaks, the citrus control on the left and the Musa tetraploid peak on the right;

- histograms with three peaks, the citrus on the left and two Musa peaks on the right corresponding to the diploid and tetraploid tissues of the chimeras.

During the whole study, more than 400 individual plants were screened by flow cytometry (table II). The quantity of plant material analysed by flow cytometry is much higher than by chromosome counts. Moreover, thanks to flow cytometry, cytochimeras directly identified at in vitro level were discarded before weaning in greenhouse. Furthermore, flow cytometry allowed a 
better selection since some clones (AA cv. Rose and Bie Yeng) evaluated as tetraploid by chromosome counts were revealed to be stable diplo-tetraploid chimeras after several years in the field. With this example, the lack of non-chimerical plants for these both varieties is analysed as a consequence of a selection of plants with 44 chromosomes in greenhouse and the capability of these $2 \mathrm{x} /$ $4 \mathrm{x}$ cytochimerical plants to produce gametes with 22 chromosomes in the field.

Flow cytometry is less time consuming than classical cytology and fits well for early mass screening of the polyploid plantlets. However, it should be emphasized that chromosome counting remains a simple and cheap method for ploidy characterization; it has been used advantageously before the availability of flow cytometry.

\subsection{Production of stable tetraploid clones}

Results (table II) show that in vitro liquid colchicine treatment succeeded in the tetraploidization over a wide range of diploid clones and gave rise to 23 non-chimerical autotetraploid clones. Chromosome-doubling has been obtained on varieties of pure $\mathrm{acu}$ minata genomic constitution as on varieties of interspecific acuminata / balbisiana constitution. Because meristematic tissues are easily and rapidly in contact with medium, liquid medium looks more suitable than semi-solid medium for the colchicine treatment phase as for the post treatment reactivation and regeneration of the doubled tissues. All the tetraploid plants were transferred to the field and they remained stable after many years of observation. No reversion to diploid level has ever been observed until today. This stability in the field might be considered as the result of an accurate in vitro selection of the plant material by flow cytometry.

A high proportion of the material regenerated after colchicine treatment proved to be chimerical with respect to its ploidy level (20 varieties). Chimerical plants have often been obtained by various authors with banana [8, 12-14]. The production of "mixoploid" plants clearly supports the hypoth-
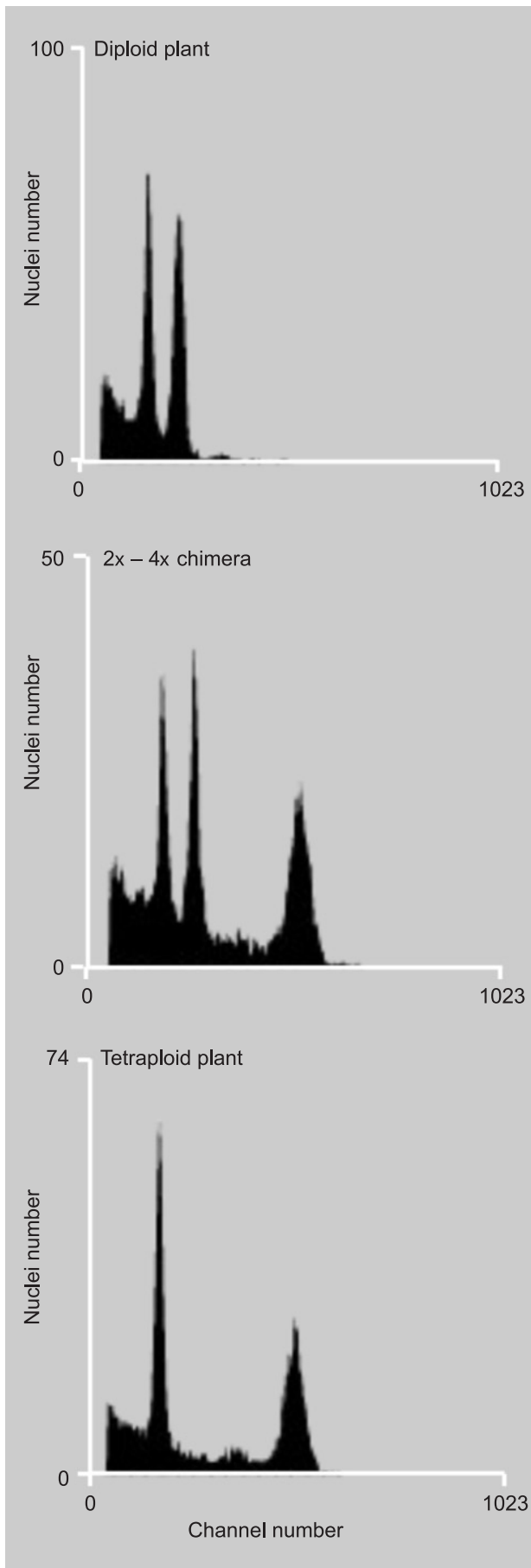

esis of a pluri-cellular origin of the in vitro induction of shoot meristems in banana.

The origin and the constitution of the stable cytochimeras observed in the field remain
Figure 2.

Histograms of relative nuclear DNA content obtained after flow cytometry using propidium iodide staining. On each histogram, the Citrus lemon peak which serves as internal reference is on the left, and the Musa peaks are on the right: $M$. acuminata peak of a diploid clone $(2 \mathrm{~N}=2 x=22)$, two $M$. acuminata peaks corresponding to $2 x / 4 x$ chimerical clones, $M$. acuminata peak of a doubleddiploid clone $(2 \mathrm{~N}=4 x=44)$. 
Figure 3.

Median longitudinal section through the shoot apex of a vitroplant of cv. Americani (Cavendish, Musa acuminata): leaf primordia encircling the central primordia dome. In vitro, anticlinal and periclinal cell divisions occur just below the epidermic L1 layer.

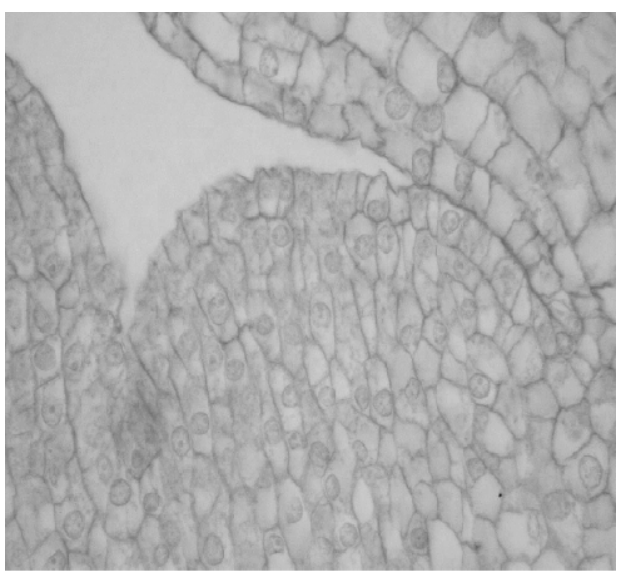

unclear. These plants are producing gamete containing 22 chromosomes whereas flow cytometry results clearly confirm their mixoploid constitution at leaf level. In banana, our own observations on in vitro grown vegetative apex show that cells below tunica are multiplying actively (figure 3; unpublished results). Thus, these cell layers are supposed to be more susceptible to the colchicine treatment than those in the more internal regions.

Barker and Steward [23] observed that cell divisions in the central area of the banana vegetative meristem are sparse in vivo, while the main organ-building and cell-multiplying functions are delegated to the lateral organs. On another hand, Fahn et al. [24] recognized five cytohistological zones in the banana vegetative shoot with a tunica at the summit of the apex. Some anticlinal and periclinal cell divisions occur in second tunica layer and in centralmother-cell zone, but more mitotic activities occur at the periphery of the apex. In Musa, it is only during the transition from the vegetative to the floral phase of the shoot that the cells in central position below tunica enter into high mitotic activity. All these observations are consistent with the hypothesis that these stable leaf mixoploid chimeras are probably periclinal and originated in the shoot apex from tetraploid tissues located in the central mother zone and diploid tissues located below $[25,26]$. Whatever be the reality, these mixoploid plants have proved to constitute a reliable plant material to study the ontogeny of the vegetative meristem in banana.

\subsection{Plant behaviour in the field}

All the doubled-diploid plants were transferred to the field and observed during several vegetative cycles. Compared to diploid plants, tetraploid ones often bear drooping leaves; they also display a global reduction of vigour and a higher inhibition of suckering. This inhibition has no consequence for varieties presenting high suckering at the diploid level (e.g., Pisang Lilin, AA Rose cv., Khai Nai On, etc.). But, it showed to be more problematic for the cooking types from Papua New Guinea (e.g., Bebeck, Bie Yeng, NBB11/SF265) since these clones, which usually manifest a high inhibition of suckering even at the diploid level, do not exhibit any suckers at the tetraploid level. In vitro culture of inflorescences [27] was thus necessary to recover new plantlets for the propagation of plant material.

The reduction of vigour observed in the tetraploid material in comparison to diploid plants has been recorded on all accuminata genotypes. This behaviour has been already reported by others authors in pineapple [28] and in Musaceae [11]. It could be linked to a global reduction of heterosis.

All the doubled-diploids flowered in the tropical conditions of Guadeloupe. These plants were used as parents in crosses with diploid clones, which resulted in the production of triploids indicating that the gametophytes derived from these plants were diploid.

\section{Conclusion}

This study has clearly shown that induction of stable doubled-diploid plants can be achieved in a wide range of genetically different bananas. Chromosome counts cannot help to detect chimeras but may be useful for a rough selection of polyploid plants when flow cytometry is unavailable. Flow cytometry has shown to be efficient for in vitro detection of chimeras and the early selection of tetraploids. Moreover, this technique allows working easily on a large number of plants.

These induced tetraploid plants have been established in the field and developed normally. The vigour decrease observed in 
the field in the doubled-diploid accuminata plants is not a constraint since their interest does not rely on their own phenotypic value but on their ability to transmit the phenotypic value of the original diploid clone to triploid progenies [29].

In our study, all plants have flowered bearing often true-to-type inflorescences with well-conformed female and male flowers. Their ability to produce diploid gametes has been verified over several cycles throughout the production of triploid progenies in crosses with diploids. Since the obtaining of $2 \mathrm{~N}$ gametes is rare and uncontrolled in banana, the implementation of in vitro chromosome doubling allows and systematizes the synthesis of triploid hybrids directly from a wide range of diploid germplasm. Henceforth, this pathway will be effectively used by our breeding program for the synthesis of enhanced triploid varieties.

\section{References}

[1] Marin D.H., Romero R.A., Guzman M., Sutton T.B., Black Sigatoka: an increasing threat to banana cultivation, Plant Dis. 87 (3) (2003) 208-222.

[2] Carreel F., Noyer J.L., Gonzalez de Leon D., Lagoda P.J.L., Perrier X., Bakry F., Tézenas du Montcel H., Lanaud C., Horry J.-P., Évaluation de la diversité génétique chez les bananiers diploïdes (Musa sp.), Genet. Sel. Evol. 26 (1) (1994) 125s-136s.

[3] Carreel F., Gonzalez de Leon D., Lagoda P.J.-L., Lanaud C., Jenny C., Horry J.-P., Tézenas du Montcel H., Ascertaining maternal and paternal lineage within Musa by chloroplast and mitochondrial DNA RFLP analyses, Genome 45 (2002) 679-692.

[4] Raboin L.-M., Carreel F., Noyer J.-L., Baurens F.C., Horry J.-P., Bakry F., Tézenas du Montcel H., Ganry J., Lanaud C., Lagoda P.J.L., Diploid ancestors of triploid export banana cultivars: molecular identification of $2 \mathrm{n}$ restitution gamete donors and $\mathrm{n}$ gamete donors, Mol. Breed. 16 (2005) 333-341.

[5] Bakry F., Carreel F., Caruana M.L., Côte F., Jenny C., Tézenas du Montcel H., Banana, in: Charrier A., Jacquot M., Hamon S., Nicolas D. (Eds.), Tropical plant breeding, CIRAD, Montpellier, France, 2001, pp. 1-29.

[6] Dodds K.S., Simmonds N.W., Genetical and cytological studies of Musa. IX. The origin of an edible diploid and the significance of interspecific hybridization in the banana complex, J. Genet. 48 (3) (1948) 285-296.

[7] Dodds K.S., The genetic system of banana varieties in relation to banana breeding, Emp. J. Exp. Agric. 11 (1943) 89-98.

[8] Vakili N.G., Colchicine induced polyploidy in Musa, Nature 194 (1962) 453-454.

[9] Dessauw D., Étude des facteurs de la stérilité du bananier (Musa spp.) et des relations cytotaxinomiques entre $M$. acuminata Colla et $M$. balbisiana Colla (II), Fruits 43 (11) (1988) 615-638.

[10] Asif M.J., Othman R.Y., In vitro zygotic embryo culture of wild Musa acuminata spp. malaccensis and factors affecting germination and seedling growth, Plant Cell Tissue Organ Cult. 67 (2001) 267-270.

[11] Tesfaye M., Agronomic and yield performance of induced-autotetraploid ensete (Ensete ventricosum) clones, Plant Genet. Resour. Newsl. 143 (2005) 56-58.

[12] Hamill S.D., Smith M.K., Dodd W.A., In vitro induction of banana autotetraploids by colchicine treatment of micropropagated diploids, Aust. J. Bot. 40 (1992) 887-896.

[13] Van Duren M., Morpurgo R., Dolezel J., Afza R., Induction and verification of autotetraploids in diploid banana (Musa acuminata) by in vitro techniques, Euphytica 88 (1996) 25-34.

[14] Ganga M., Chezhiyan N., Influence of the antimitotic agents colchicine and oryzalin on in vitro regeneration and chromosome doubling of diploid bananas (Musa spp.), J. Hortic. Sci. Biotechnol. 77 (5) (2002) 572-575.

[15] Murashige T., Skoog F., A revised medium for rapid growth and bio assays with tobacco tissue cultures, Physiol. Plantarum 15 (1962) 473-497.

[16] Morel G., Wetmore R.H., Fern callus tissue culture, Ann. J. Bot. 38 (1951) 141-143.

[17] Bakry F, Horry J.-P., Tetraploid hybrids from interploid $3 x / 2 x$ crosses in cooking bananas, Fruits 47 (6) (1992) 641-655.

[18] Dolezel J., Binarova P., Lucretti S., Analysis of nuclear DNA content in plant cells by flow cytometry, Biol. Plantarum 31 (1989) 113120.

[19] Ollitrault P., Dambier D., Luro F., Duperray C., Nuclear genome size variations in Citrus, Fruits 49 (5-6) (1994) 390-393.

[20] Arumuganathan K., Earle E.D., Nuclear DNA content of some important plant species, Plant Mol. Biol. Report 9 (3) (1991) 208-218. 
[21] Bakry F., Rossignol L., Analyse des capacités de callogenèse et d'organogenèse obtenues à partir de différents tissus de bananiers (Musa sp., Musacées), Fruits 40 (11) (1985) 697-708.

[22] Galbraith D.W., Lambert G.M., Macas J., Dolezel J., Analysis of nuclear DNA content and ploidy in higher plants, in: Robinson J.P., Darzynkiewicz Z., Deanet P.N., Orfao A., Rabinovitch P.S., Stewart C. C., Tanke H. J., Wheeless L. (Eds.), Current protocols in cytometry, John Wiley \& sons, New York, USA, 1997, pp. 7.6.1-7.6.22.

[23] Barker W.G., Steward F.C., Growth and development of the banana plant. I. The growing regions of the vegetative shoot, Ann. Bot. 26 (103) (1962) 390-410.

[24] Fahn A., Stoler S., First T., Vegetative shoot apex in banana and zonal changes as it becomes reproductive, Bot. Gaz. 124 (4) (1963) 246-250.
[25] Dermen H., The nature of plant sports, Am. Hortic. Mag. 39 (1960) 123-173.

[26] Stewart R.N., Dermen H., Ontogeny in monocotyledons as revealed by studies of the developmental anatomy of periclinal chloroplast chimeras, Am. J. Bot. 66 (1) (1979) 47-58.

[27] Bakry F., Lavarde-Guignard F., Rossignol L., Demarly Y., Développement de pousses végétatives à partir de la culture in vitro d'explants inflorescentiels de bananiers (Musa sp., Musacées), Fruits 40 (7-8) (1985) 459-465.

[28] Kerns K.R., Collins J.L., Chimeras in the pineapple: colchicine-induced tetraploids and diploid-tetraploids in the Cayenne variety, J. Hered. 38 (1947) 323-330.

[29] Sanford J.C., Ploidy manipulations, in: Moore J.N., Janick J. (Eds.), Methods in fruit breeding, Purdue Univ. Press, West Lafayette, Indiana, USA, 1983, pp. 100-123.

\section{La colchicina aplicada en medio líquido induce diploides doblados no quiméricos, en una amplia gama de clones de plataneros diploidos mono o interespecíficos.}

Resumen - Introducción. La producción mundial de plátanos y llantenes, que se estima a $\mathrm{Mt} \cdot a n ̃{ }^{-1}$, se basa en una estrecha base genética. Por lo tanto la producción de plátanos es débil respecto a las enfermedades emergentes, y la creación de variedades nuevas aparece como una necesidad real para su perennidad. Las diversas estrategias de mejora del platanero pretenden crear híbridos triploides. El objetivo de este artículo es presentar un método fácil de producción de plantas tetraploides estables mediante tratamiento de colchicina aplicada in vitro, de modo a que se utilicen como progenitor con el fin de obtener nuevas variedades híbridas triploides. Material y métodos. Se trataron durante la fase de proliferación in vitro en un medio líquido con $1.25 \mathrm{mM}$ de colchicina durante $48 \mathrm{~h}$, veintiún clones diploidos de $M$. acuminata así como tres clones diploidos interespecíficos M. acuminata / M balbisiana. La clasificación de los plantones se efectuó mediante una identificación morfológica en invernadero, el recuento de los cromosomas se llevó a cabo en las puntas de las raíces, y la citometría de flujo se hizo sobre las hojas de vitroplantones utilizando para ello yoduro de propidium como colorante. Resultados. El recuento de los cromosomas fue eficaz para distinguir los plantones diploidos y tetraploidos, pero no logró detectar las quimeras. La citometría de flujo permitió un cribado precoz de un número de plantones mayor, y condujo a la rápida detección de plantones quiméricos. Se tomó nota que ciertas citoquimeras $2 x / 4 x$ estables eran periclinales. Se obtuvieron clones tetraploidos con la totalidad de los genotipos diploides. De modo general, los tetraploides en campo labrado resultaron ser menos vigorosos que los diploides correspondientes. No obstante, todos los diploides doblados florecieron y se cruzaron con plantones diploides para obtener descendencias triploides. Conclusión. Nuestro estudio mostró claramente que la inducción de plantones estables de diploidos doblados puede obtenerse a partir de una amplia gama de plataneros genéticamente diferentes. Los resultados en cuestión abren la vía a la utilización sistemática de diploidos doblados para los programas de mejora para la obtención de variedades triploides mejoradas de plataneros.

Guadalupe / Musa / cultivo de tejidos / colchicina / número de cromosomas / tetraploidia / quimera 